
(Ninho Moraes)

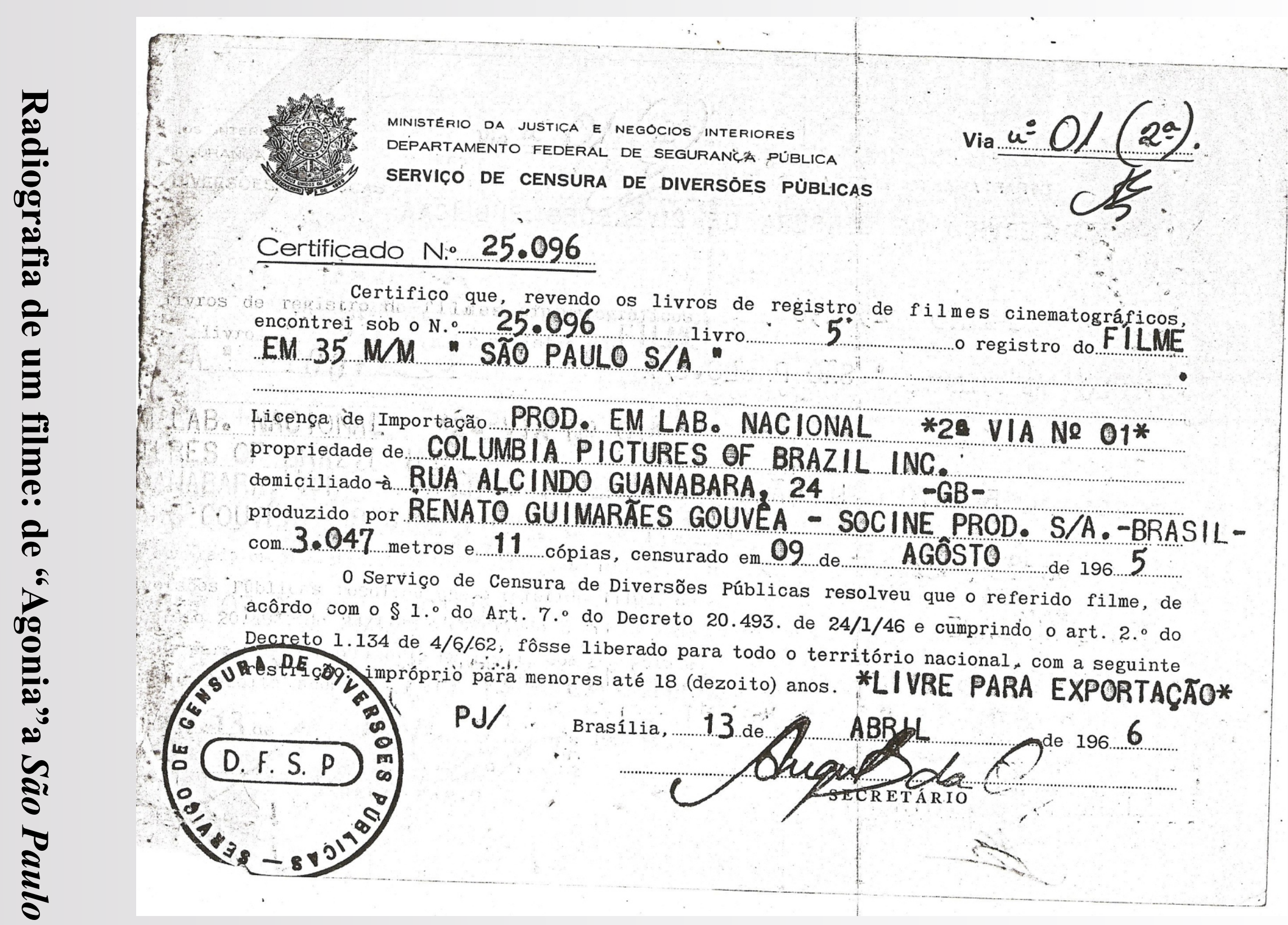

ڤ్

\title{
RADIOGRAFIA DE UM FILME: DE "AGONIA" \\ A SÃO PAULO SOCIEDADE ANÔNIMA
}

